\title{
PIAS1-modulated Smad2/4 complex activation is involved in zinc-induced cancer cell apoptosis
}

\author{
N Yang ${ }^{1}$, B Zhao ${ }^{1}$, A Rasul ${ }^{1}, \mathrm{H}$ Qin ${ }^{1}, \mathrm{~J} \mathrm{Li}^{*, 2}$ and X Liं
}

Prostate cancer is one of the most frequently diagnosed cancers among men. Dietary intake of nutrients is considered crucial for preventing the initiation of events leading to the development of carcinoma. Many dietary compounds have been considered to contribute to cancer prevention including zinc, which has a pivotal role in modulating apoptosis. However, the mechanism for zinc-mediated prostate cancer chemoprevention remains enigmatic. In this study, we investigated the therapeutic effect of zinc in prostate cancer chemoprevention for the first time. Exposure to zinc induced apoptosis and resulted in transactivation of p21 ${ }^{\text {WAF } 1 / C i p 1}$ in a Smad-dependent and p53-independent manner in prostate cancer cells. Smad2 and PIAS1 proteins were significantly upregulated resulting in dramatically increased interactions between Smad2/4 and PIAS1 in the presence of zinc in LNCaP cells. Furthermore, it was found that the zinc-induced Smad4/2/PIAS1 transcriptional complex is responsible for Smad4 binding to SBE1 and SBE3 regions within the p21 WAF1/Cip1 promoter. Exogenous expression of Smad2/4 and PIAS1 promotes zinc-induced apoptosis concomitant with Smad4 nuclear translocation, whereas endogenous Smad2/4 silencing inhibited zincinduced apoptosis accompanying apparent p21 ${ }^{W A F 1 / C i p 1}$ reduction. Moreover, the knockdown of PIAS1 expression attenuated the zinc-induced recruitment of Smad4 on the p21 ${ }^{W A F 1 / C i p 1}$ promoter. The colony formation experiments demonstrate that PIAS1 and Smad2/4 silencing could attenuate zinc apoptotic effects, with a proliferation of promoting effects. We further demonstrate the correlation of apoptotic sensitivity to zinc and Smad4 and PIAS1 in multiple cancer cell lines, demonstrating that the important roles of PIAS1, Smad2, and Smad4 in zinc-induced cell death and p21 ${ }^{\text {WAF1/Cip1 }}$ transactivation were common biological events in different cancer cell lines. Our results suggest a new avenue for regulation of zinc-induced apoptosis, and provide a model that demonstrates zinc endorses the Smad2/4/PIAS1 complex to activate the p21 ${ }^{\text {WAF1/Cip1 }}$ gene that mediates apoptosis. Cell Death and Disease (2013) 4, e811; doi:10.1038/cddis.2013.333; published online 19 September 2013

Subject Category: Cancer

Prostate cancer is the most common malignancy in men in the west world and has markedly increased in the last two decades in Asian countries. ${ }^{1,2}$ Increasing clinical and experimental evidence suggest a potential role of zinc in human malignancies, including prostate cancer. ${ }^{3}$ Normal human prostate glands accumulate almost 10 times more zinc than other soft tissues, such as liver and kidney, and significantly decreased zinc levels are shown in malignant prostate tissues. ${ }^{3-7}$ Most human prostate cancer develops from the peripheral zone of the prostate, where high levels of zinc are identified in the normal epithelium, but dramatically lower levels in the tumor. $^{3-7}$ Exogenous zinc showed an anti-proliferation effect in prostate cancer cells via induction of mitochondrial apoptogenesis. ${ }^{3,8}$ Increasing evidence has shown a link between the reduction of intracellular zinc concentrations and human tumor development. ${ }^{7}$ However, the mechanisms underlying the zinc-mediated anti-tumor effect still remain largely unknown.
Zinc affects cell cycle and apoptosis by increasing the ratio of Bax to Bcl-2, which further upregulates the p21 WAF1/Cip1 mRNA level in prostate cancer. ${ }^{8-10}$ The regulation of the cell cycle through modulation of $\mathrm{p} 21^{\text {WAF1/Cip } 1}$ is considered to be an intrinsic characteristic of many tumor suppressor proteins, including p53, BRAC1, and Smads. ${ }^{9,11-15}$ TGF- $\beta$-activating $\mathrm{R}$-Smad/Co-Smad complex directly activates the promoter region of the $\mathrm{p} 21^{\text {WAF1/Cip } 1}$ gene and upregulates cyclindependent kinase (CDK) inhibitors to promote G1-S cell cycle arrest. ${ }^{13,14}$ Impairment of the Smad pathway causes escape from growth inhibition and leads to the promotion of cell proliferation, thereby contributing to carcinogenesis. ${ }^{16-19}$ The re-establishment of the Smad4-involved complexes may reverse tumor cell development and shed light into therapeutic strategies for cancer treatment. ${ }^{20}$

It has been shown that protein inhibitors of activated signal transducers and activators of transcription (PIAS) proteins interact with the TGF- $\beta$ pathway and regulate Smad-mediated transcriptional activity. ${ }^{21-23}$ The PIAS proteins are implicated

\footnotetext{
${ }^{1}$ The Key Laboratory of Molecular Epigenetics of MOE, Institute of Genetics and Cytology, Northeast Normal University, Changchun 130024, China and ${ }^{2}$ Dental Hospital, Jilin University, Changchun 130021, China

*Corresponding authors: Xiaomeng Li, The Key Laboratory of Molecular Epigenetics of MOE, Institute of Genetics and Cytology, Northeast Normal University, Changchun 130024, China. Tel: +86 131 96048876; Fax: +86 431 85099285; E-mail: lixm441@ @nenu.edu.cn

or Jiang Li, Dental Hospital, Jilin University, Changchun 130021, China. Tel: +86 186 86531019; Fax: +86 431 85579335; E-mail: lijiang69@yahoo.com.cn

Keywords: PIAS1; Smad2; Smad4; zinc; prostate cancer

Abbreviations: PIAS, protein inhibitor of activated signal; TGF- $\beta$, transforming growth factor-beta; $\mathrm{ZnSO}_{4}$, zinc sulfate; EDTA, ethylenediaminetetraacetic acid; SBE, Smad-binding element; ChIP, chromatin immunoprecipitation; shRNA, short hairpin RNA; FBS, fetal bovine serum; SDS, sodium dodecyl sulfate; IGF-I, insulin-like growth factor-l; Bcl-2, B-cell lymphoma 2; Bax, Bcl-2-associated X protein; BRAC1, breast cancer gene 1; CDKs, cyclin-dependent kinases; AR, androgen receptor; $\mathrm{PI}$, propidium iodide; DTT, dithiothreitol; DAPI, 4', 6-diamidino-2-phenylindole

Received 28.5.13; revised 05.8.13; accepted 06.8.13; Edited by A Stephanou
} 
in apoptotic pathways, such as Smad, p53, and AR signaling. ${ }^{24-26}$ PIAS1 is shown to be the downregulated factor screened from 16 AR coactivators in hormone-refractory prostate tumors as compared with benign prostatic hyperplasia. ${ }^{27}$ Moreover, substantially reduced expression of PIAS1 is indicated to be associated with the development of both colon cancer and gastric cancer, suggesting its important roles in cancer. ${ }^{28-30}$ Notably, PIAS proteins contain a RING finger-like zinc-binding domain; however, the roles of PIAS proteins in zinc-induced apoptosis have not been addressed yet. The increased p21 ${ }^{\text {WAF1/Cip } 1}$ expression by zinc treatment in LNCaP (androgen-dependent) and PC3 cells (androgenindependent) has been well documented. ${ }^{8,9,31,32}$ However, their associated pathways are still unclear. Therefore, this study was conducted to determine the potential contribution of the PIAS-Smad signaling in zinc-induced apoptosis.

\section{Results}

Zinc treatment resulted in the overexpression of Smad and PIAS in prostate cancer cells. To examine the apoptotic effect of zinc on human prostate cancer cells, flow cytometric analyses were performed. Figure 1a demonstrates that with ZnSO4 $(150 \mu \mathrm{M})$ treatment, an estimated $20 \%$ of cells progressed to sub-G1 cell fraction in both $\mathrm{LNCaP}$ and $\mathrm{PC} 3$ cells. To determine whether
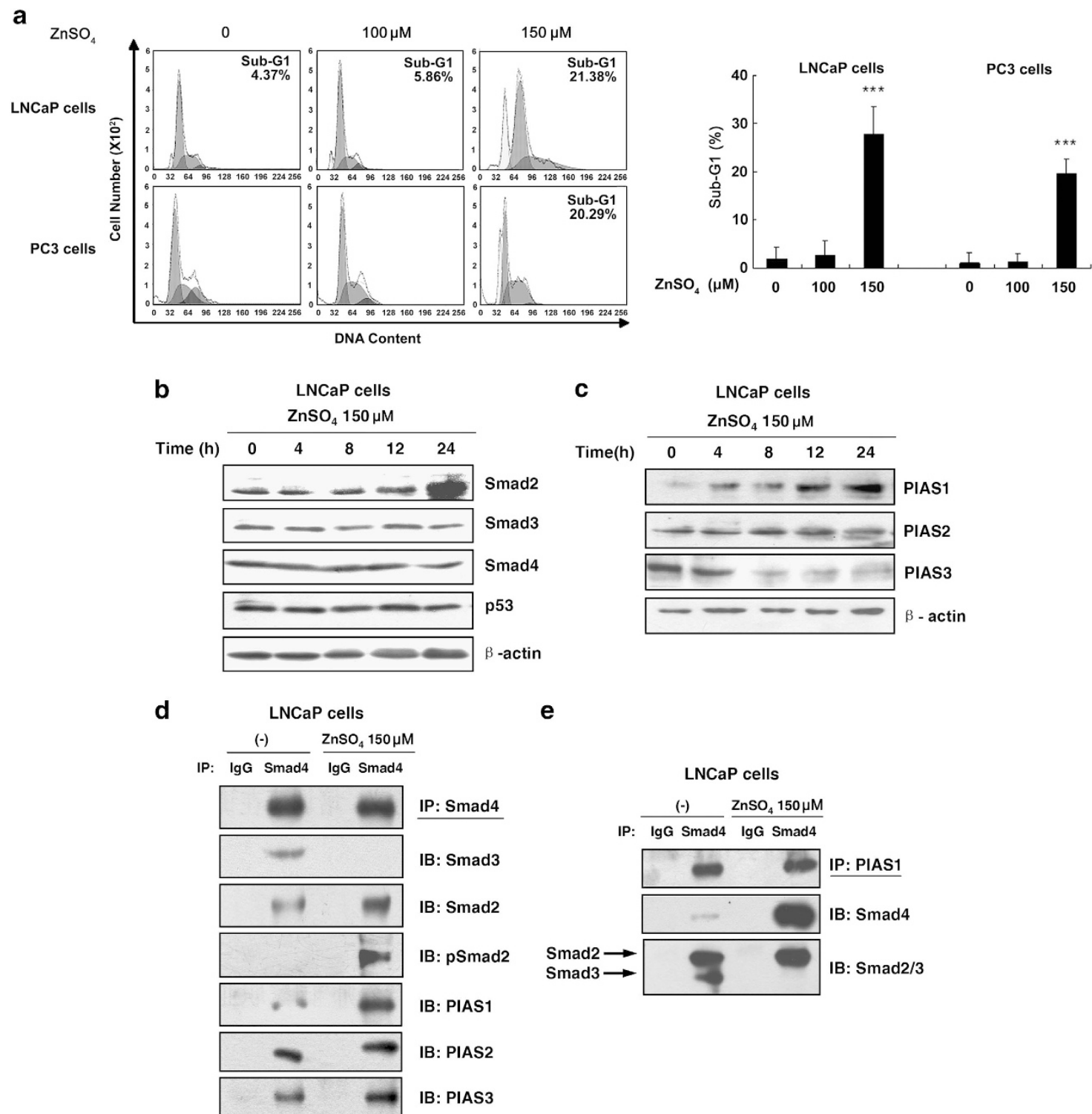

e

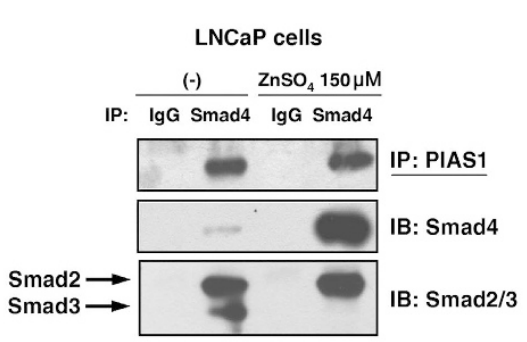
androgen-dependent LNCaP or androgen-independent PC3 prostate cancer cells. LNCaP and PC3 cells were treated with indicated concentrations of $\mathrm{ZnSO}_{4}$ for $24 \mathrm{~h}$. Sub-G1 populations were detected using flow cytometry. Columns, mean $\left(n=3\right.$ ); bars, S.D.; ${ }^{\star \star \star} P<0.001$ (one-way ANOVA). (b) Zinc selectively increased Smad2 and PIAS1 expression. LNCaP cells were treated with $150 \mu \mathrm{M} \mathrm{ZnSO}_{4}$ for indicated periods $(0,4,8,12$ and $24 \mathrm{~h}$ ). Immunoblot analyses were performed with antibodies of Smad3, Smad2, Smad4 or $\beta$-actin and PIAS1, PIAS2 and (c) PIAS3 or $\beta$-actin. (d and $\mathbf{e}$ ) The immunoprecipitation experiments with anti-Smad4 or anti-PIAS1 were carried out in LNCaP cells with or without $150 \mu \mathrm{M}$ zinc treatment and then analyzed by immunoblot analysis using the indicated antibodies against Smad4, Smad3, Smad2, phosphorylated Smad2, PIAS1, PIAS2, or PIAS3 (d), or against PIAS1, Smad4, or Smad2/3 (e) 
PIASs, as RING zinc-finger proteins and Smad-interacting proteins, ${ }^{21-23}$ are involved in the zinc-induced apoptosis, we next examined the expression of Smad and PIAS proteins in zinc $(150 \mu \mathrm{M})$-treated LNCaP cells. As shown in Figures $1 \mathrm{~b}$ and $\mathrm{c}$, there was a significant increase in the expression of Smad2 and PIAS1 in zinc $(150 \mu \mathrm{M})$-treated LNCaP cells in a time-dependent manner. We also examined the effect of zinc $(150 \mu \mathrm{M})$ on Smad3, Smad4, PIAS2 and p53, and observed that zinc did not alter the expression of these proteins within this time frame (Figures $1 \mathrm{~b}$ and $\mathrm{c}$ ). These results indicated the possible role of Smad2 and PIAS1 in zinc-induced apoptosis.

Zinc regulates the Smad2/4 and PIAS1 complex formation. To assess the effect of zinc on the Smad protein complexes formation, co-immunoprecipitation analyses were employed. Figure 1d illustrates that with zinc $(150 \mu \mathrm{M})$ treatment, interaction between Smad3 and Smad4 was significantly reduced in $\mathrm{LNCaP}$ cells. However, dramatically increased Smad2 or phosphorylated Smad2 and Smad4 interactions were observed in the presence of zinc. In addition, it appears that PIAS1, but not PIAS2 and PIAS3, strongly increased interaction with Smad4 by zinc treatment, although Smad4 interacted with all of them in the absence of zinc. These results suggested that zinc $(150 \mu \mathrm{M})$ promoted Smad4, Smad2 and PIAS1 ternary complex formation, which is consistent with the increase of Smad2 and PIAS1 levels in response to zinc.

To confirm our observation, reverse co-immunoprecipitation analyses were performed using the specific PIAS1 antibody (Figure 1e). A dramatically increased interaction of Smad4 binding to PIAS1 was detected in the zinc-treated LNCaP cells. Meanwhile, in the absence of zinc, PIAS1 exhibited interactions with both Smad2 and Smad3. In contrast, in the presence of zinc, PIAS1 displayed the interaction only with Smad2, but not with Smad3. We repeated the above experiments in PC3 cells and similar results were observed (data not shown). The above data demonstrated that zinc regulates the Smad2/4 and PIAS1 involved complex formation.

Zinc enhances the recruitment of Smad2/4/PIAS complex on the p21 WAF1/Cip1 promoter. We further used a zinc ion chelating agent, EDTA (CaEDTA) (Figure 2a), ${ }^{33,34}$ to validate the specificity for zinc-induced cell apoptosis. In both LNCaP and PC3 cell lines, the apoptotic sub-G1 cell fractions induced by exogenous zinc $(150 \mu \mathrm{M})$ could be blocked by EDTA (either $150 \mu \mathrm{M}$ or $1 \mathrm{mM}$ ), suggesting the reduction of zinc level is related to the loss of apoptotic ability in prostate cancer cells.

Because p21 ${ }^{\text {WAF1/Cip } 1}$ is a cyclin-dependent kinase inhibitor and involved in cell growth arrest, ${ }^{11}$ we further observed the upregulation of p21 WAF1/Cip1 levels in the zinc $(150 \mu \mathrm{M})$ treated LNCaP and PC3 cells (Figure $2 b$ ). This enhancement of p21 levels corresponding to the apoptotic process was significantly blocked by the zinc ion chelating agents, EDTA, in a dose-dependent manner, demonstrating that cell growth arrest regulation was significantly dependent on cellular zinc ion levels.
Previous studies have shown that $\mathrm{p} 21^{\text {WAF1/Cip } 1}$ is a potent cell cycle inhibitor downstream of either p53 or Smad tumor suppressor proteins. ${ }^{9,11-15}$ To determine the pathway involved in zinc-induced p21 WAF1/Cip1 transactivation, two p21 ${ }^{\text {WAF1/Cip } 1}$ promoter-driven luciferase reporters were initially adopted for zinc treatment (Figure 2c). There were significant elevations of $\mathrm{p} 21^{\text {WAF1/Cip } 1}$ promoter-driven luciferase activities for both $\mathrm{p} 21 \mathrm{P}$-luc and $\mathrm{p} 21 \mathrm{P} \Delta \mathrm{p} 53$-luc reporters in the zinc-treated LNCaP cells in a dose-dependent manner, reaching maximal level, which is about threefold of control after $150 \mu \mathrm{M}$ zinc concentration treatment, suggesting that the p21 ${ }^{\text {WAF } 1 / C i p 1}$ promoter was capable of being activated by zinc, even without p53 binding. To further confirm the involved pathways, a pp53-TA-luc reporter containing p53-binding sites and a $4{ }^{\star} \mathrm{SBE}-\mathrm{luc}$ reporter, the most frequently used reporter for TGF- $\beta$-Smad signaling, were used for the next experiments. The activity of $4^{\star} \mathrm{SBE}-\mathrm{luc}$ was enhanced to 2.6 fold of control after $150 \mu \mathrm{M}$ zinc concentration treatment (Figure 2d), whereas pp53-TA-luc was not enhanced by zinc (Figure $2 \mathrm{e}$ ). These results revealed that zinc could activate p21 ${ }^{\text {WAF } 1 / C i p 1}$ transcription in a Smad-dependent manner.

Smad proteins, which include certain R-Smads and Co-Smads, specifically recognize an 8-bp Smad-binding element (SBE) (GTCTAGAC) in downstream gene promoters to activate transcription. ${ }^{13}$ To ascertain the direct recruitment of the Smad complex on the p21 $1^{\text {WAF } 1 / C i p 1}$ promoter, chromatin immunoprecipitation (ChIP) assays were performed with Smad4 or Smad3 antibodies in LNCaP cells. Comparison was made among the SBE1 $(-1800 \sim-1500)$, the SBE2 $(-1500 \sim-1200)$, the SBE3 $(-1000 \sim-750)$, and a TATA box fragment of p21 ${ }^{\text {WAF1/Cip } 1}$ promoter as a negative control (Figure 3a). ChIP results showed that Smad4 occupancy was apparently increased at SBE1/SBE3 in the presence of zinc, whereas no Smad3 recruitments to the $\mathrm{p} 21^{\text {WAF1/Cip } 1}$ promoter were found (Figure $3 \mathrm{~b}$ ). These data suggested the direct increased recruitment of Smad4 on the $\mathrm{p} 21^{\text {WAF } 1 / \text { Cip } 1}$ promoter in response to zinc.

To probe the relationship between Smad4 and R-Smad (2/3), or between Smad4 and PIAS on the p21 WAF1/Cip1 promoter, we performed two sets of re-ChIP assays as described in Materials and methods. As shown in Figure 3c, the presence of Smad2 on SBE1 and SBE3 sites within the p21 WAF1/Cip1 promoter was detected in response to the addition of zinc $(150 \mu \mathrm{M})$ in the immunoprecipitates. Using the PIAS1 antibody, we also detected the presence of Smad4 on SBE1 and SBE3 regions within the p21 WAF1/Cip1 promoter (Figure $3 d$ ). These results provided a line of evidence demonstrating that zinc can induce the Smad4/2/PIAS1 transcriptional complex, which is responsible for Smad4 binding to SBE1 and SBE3 regions in the $\mathrm{p} 21^{\text {WAF1/Cip1 }}$ promoter.

\section{Exogenous PIAS1 and Smad4 coordinately promote zinc-induced apoptosis and Smad4 nuclear translocation. To gain insight into the biological signifi- cance of Smad4 and PIAS1 in zinc-induced apoptosis, we tested directly whether the exogenous Smad4 and PIAS1 could sensitize zinc-mediated apoptosis in prostate cancer cells. As $150 \mu \mathrm{M}$ of zinc is capable of inducing apoptosis in prostate cancer cells via upregulation of Smad4 and PIAS1,}




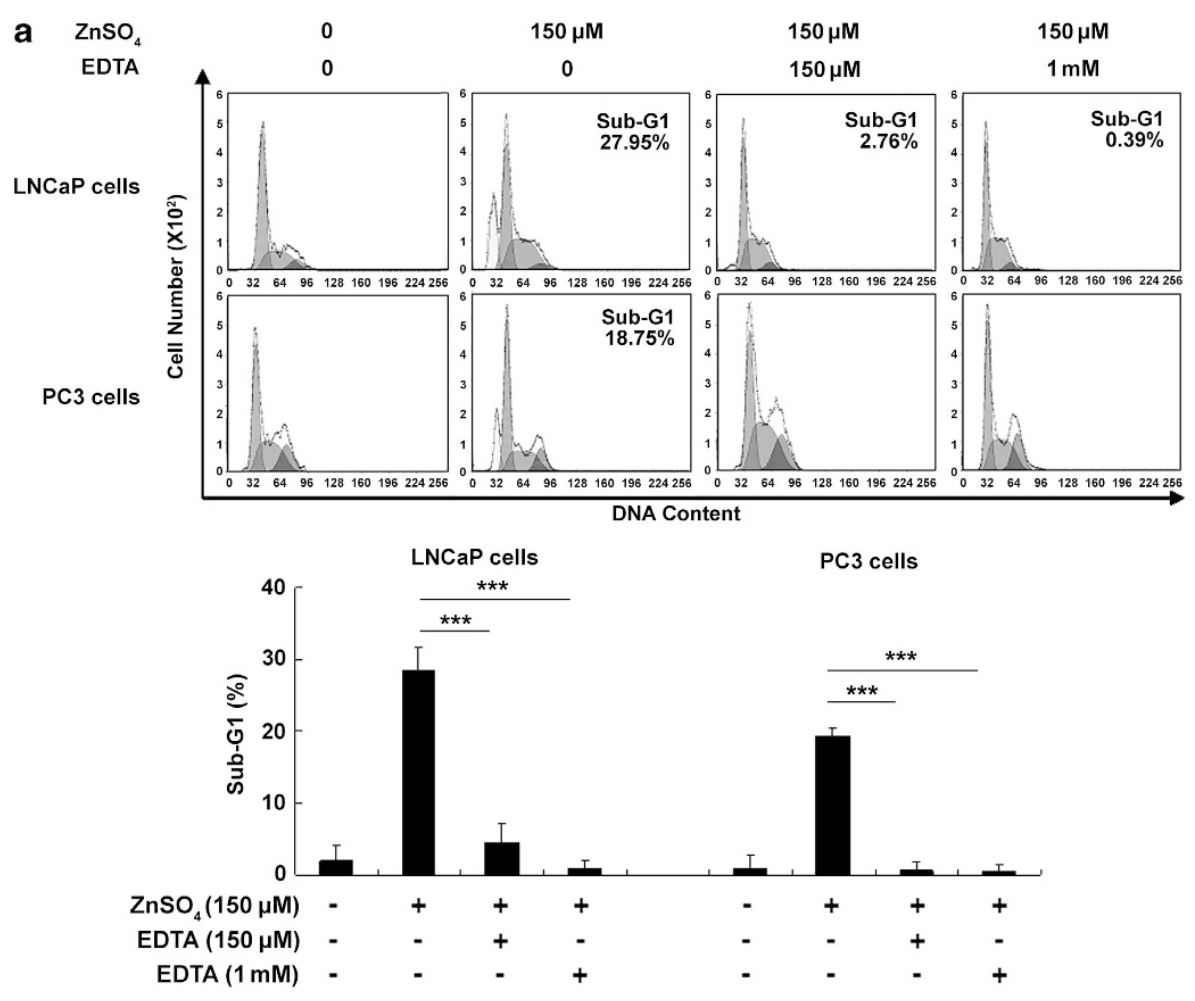

b
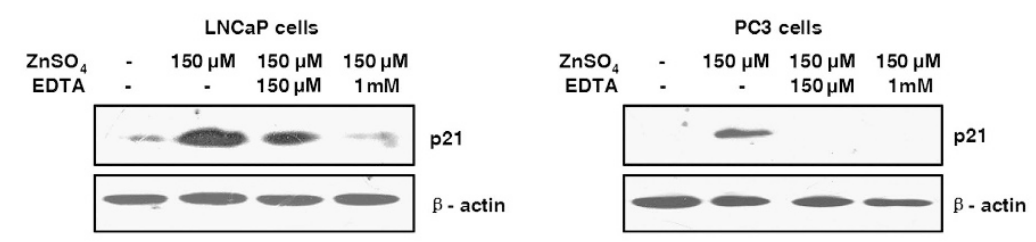

C
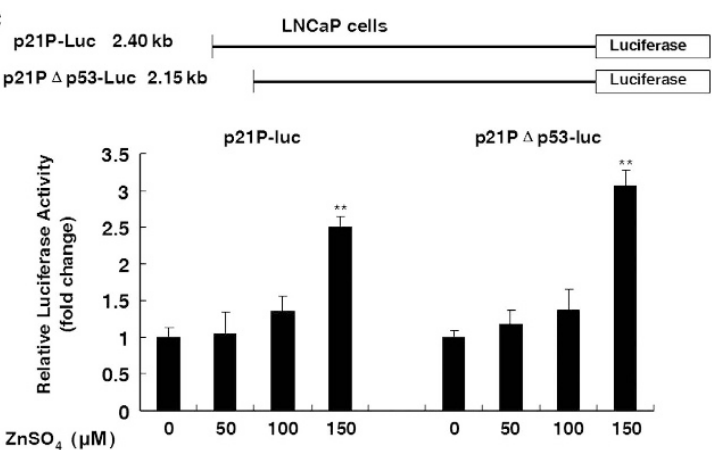

d

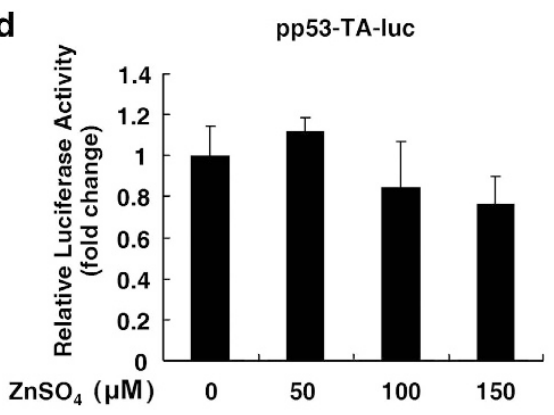

e

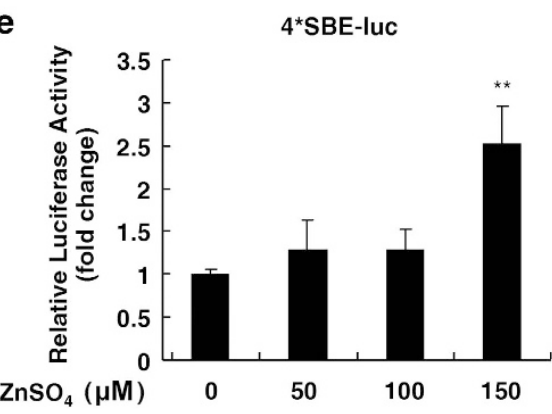


we reasoned that exogenous addition of Smad4 and PIAS1 should enhance this effect, thereby sensitizing apoptosis induced by zinc. Therefore, LNCaP cells were cotransfected with plasmid, either Smad4 or PIAS1, by zinc ( $100 \mu \mathrm{M}$ of zinc simulation that can only induce less than 5\% apoptosis alone) or a combination thereof, and assayed for apoptosis through flow cytometric analysis. Interestingly, the apoptotic rate was dramatically increased to near $90 \%$ in the co-expression of Smad4 and PIAS1, but not PIAS2 or PIAS3, suggesting the synergistic effects of Smad4 and PIAS1 on zinc-induced apoptosis (Figure 4a). These results not only further confirmed that Smad4 and PIAS1 have a crucial role in zinc-induced apoptosis but also endorsed our above findings.

To further investigate the role of Smad4 and PIAS1 in regulating zinc-induced apoptosis, we examined zincstimulated cellular localization of Smad4 and PIAS1 proteins in LNCaP cells. Immunostaining analysis revealed that exogenously expressed Smad4 and PIAS1 proteins are distributed in the cytoplasm in the absence of zinc. In contrast, with exposure to zinc (even at low concentration, $100 \mu \mathrm{M}$ ), exogenous expression of Smad4 alone resulted in the partial translocation of Smad4 from the cytoplasm to nucleus, and cotransfected with both PIAS1 and Smad4 plasmids, the significant shift of Smad4 and PIAS1 from the cytoplasm to nucleus was observed, accompanied with the apoptotic condensed phenotype in DAPI staining (Figure 4b). These results suggest that PIAS1 enhances Smad4 nuclear localization in the presence of zinc.

Smad4 and Smad2 are critical for zinc-induced prostate cancer cell apoptosis. Previous studies have demonstrated that both Smad3/4 and Smad2/4 cause high levels of transcriptional activation of the p21 WAF1/Cip1 promoter, involved in cell apoptosis. ${ }^{35,36}$ These findings prompted us to investigate the involvement of endogenous Smad4 and Smad2 in zinc-induced apoptosis using gene-silencing approaches. The short hairpin RNA (shRNA) constructs for Smad4 or Smad2 were generated and their knockdown effects were tested on ectopically expressed proteins in LNCaP cells. The Smad4-shRNA1 and Smad2-shRNA1, which have been shown to be more effective in Smad expression knockdown (Figure 5a), were selected to examine the attenuation effects on zinc-induced Smad4mediated p21WAF1/Cip1 transactivation and apoptosis. As presented in Figures $5 \mathrm{~b}$ and $\mathrm{c}$, disruption of either endogenous Smad4 or Smad2 in zinc-stimulated LNCaP cells resulted in apparent reduction either in zinc-induced p21 WAF1/Cip 1 induction or in the zinc-mediated proportion of cells in the sub-G1 phase. In addition, the depletion of both Smad4 and Smad2 together causes the most dramatic decline in the sub-G1 phase, suggesting Smad2/4 silencing significantly reduces the cell apoptotic sensitivity to zinc. These data demonstrated that Smad4 and Smad2 have critical roles in zinc-induced cell apoptosis.

\section{Endogenous PIAS1 is essential for zinc-induced Smad2/} 4-mediated apoptosis. To determine the role of endogenous PIAS1 in zinc-induced Smad activation and apoptosis, two PIAS1-shRNAs were generated and finally, shRNA1 (most effective) was selected (Figure 6a). Our data reveal that zinc-induced Smad4 recruitment on SBE1 and SBE3 regions of the $\mathrm{p} 21^{\text {WAF } 1 / C i p 1}$ promoter was significantly reversed by PIAS1-shRNA1 as compared with the control vector (Figure 6b). Moreover, Figure $6 c$ shows that silencing PIAS1 potently inhibited exogenous Smad2/4-mediated zincinduced apoptosis, indicating endogenous PIAS1 has essential roles in zinc-induced Smad activation and apoptosis.

Silencing PIAS1 and Smad2/4 attenuates zinc-impeded clonogenic ability in LNCaP cells. To investigate whether zinc affects the clonogenicity either alone or combined with shRNAs of Smad2/4 and PIAS in LNCaP cells, we assessed zinc together with shRNAs and control LNCaP cells in culture using soft agar colony formation assay. As shown in Figure $6 \mathrm{~d}$, few colonies were observed in zinc $(150 \mu \mathrm{M})$ treated cells after 12 days while introduction of Smad4shRNA, Smad2-shRNA or PIAS1-shRNA into LNCaP cells increased the colony formation. The number and size of colonies were further increased in cells, which were treated with both Smad2/4-shRNAs and in those which were treated with all the three shRNAs of Smad2/4 and PIAS, compared with the base line cells. These results reveal that with the silencing of PIAS1 and Smad2/4, cell proliferation capacity is upregulated, suggesting a promoting role of Smad2/4 and PIAS1 in zinc-mediated apoptosis.

Correlation of apoptotic sensitivity to zinc and Smad4 and PIAS1 in multiple cancer cell lines. Exogenous zinc has been shown to promote apoptosis in various kinds of cancer cells. $^{7,37}$ To assess the involvement of the PIAS1/ Smad2/4 complex in zinc-induced apoptosis as a common event for other cell types, the correlation between the expression level of PIAS1 or Smad2/4 and cell apoptotic sensitivity response to zinc in six tumor cell lines was examined. As shown in Figures $7 a$ and $b$, three cells lines, including two prostate cancer (LNCaP and PC3) cells and one breast cancer MDA-MB-231 cell line, all had PIAS1, Smad2 and Smad4-positive expression, and were sensitive to zinc-induced cell growth inhibition. In contrast, the other three cells lines, including one breast cancer MCF-7 cell line,

\footnotetext{
Figure 2 The p21 $1^{\text {Waf1/Cip1 }}$ upregulation and activation corresponding to apoptotic process induced by zinc: (a) zinc-augmented p21 ${ }^{\text {WAF1/Cip1 }}$ expression. (a) Zinc ion chelating agents blocked zinc-induced apoptotic effect. LNCaP and PC3 cells were exposed to $150 \mu \mathrm{M} \mathrm{ZnSO}_{4}$ in the presence or absence of zinc inhibitor of $150 \mu \mathrm{M}$ or $1 \mathrm{mM}$ CaEDTA for $24 \mathrm{~h}$. Sub-G1 populations were detected using flow cytometry. Columns, mean ( $n=3$ ); bars, S.D.; ${ }^{\star \star \star} P<0.001$ (one-way ANOVA). (b) Zinc-augmented p21 ${ }^{\text {WAF1/Cip1 }}$ expression. LNCaP and PC3 cells were exposed to $150 \mu \mathrm{M} \mathrm{ZnSO}$ in the presence or absence of zinc inhibitor of $150 \mu \mathrm{M}$ or $1 \mathrm{mM}$ CaEDTA for $24 \mathrm{~h}$. The p21 $1^{\text {WAF1/Cip } 1}$ levels were examined by immunoblot analysis with either p21 $1^{\text {WAF1/Cip1 }}$ or $\beta$-actin antibody. (c) Zinc increased p2 $1^{\text {WAF1/Cip1 }}$ transactivation in a Smad-dependent manner. LNCaP cells were cotransfected with $25 \mathrm{ng}$ of Renilla luciferase reporter and $100 \mathrm{ng}$ of luciferase reporter, p21P-luc or p21P $\Delta$ p53-Iuc (c), pp53-luc (d) or 4*SBE-luc (e) as indicated, and then were exposed to various concentrations of $\mathrm{ZnSO} 4$ for $24 \mathrm{~h}$. Relative luciferase activities were measured and calculated by the ratio of the firefly luciferase activity to Renilla luciferase. Columns, mean $(n=5)$; bars, S.D.; ${ }^{\star \star} P<0.01$ (one-way ANOVA)
} 
a

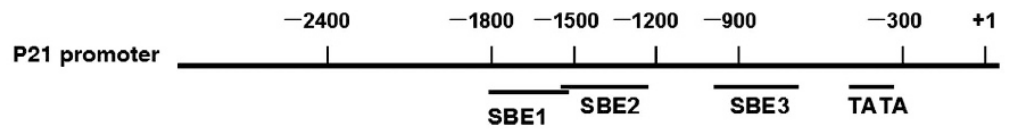

b

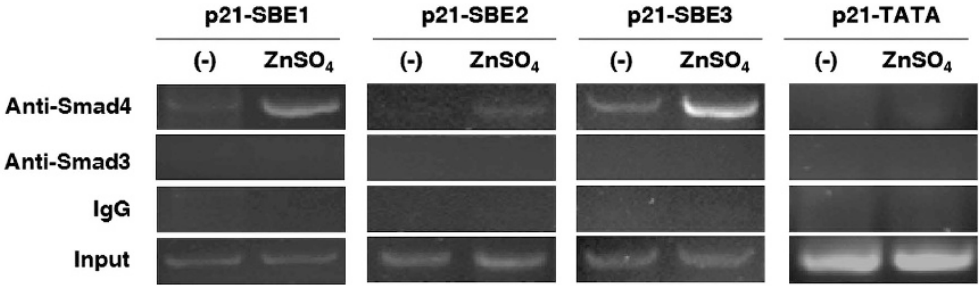

C
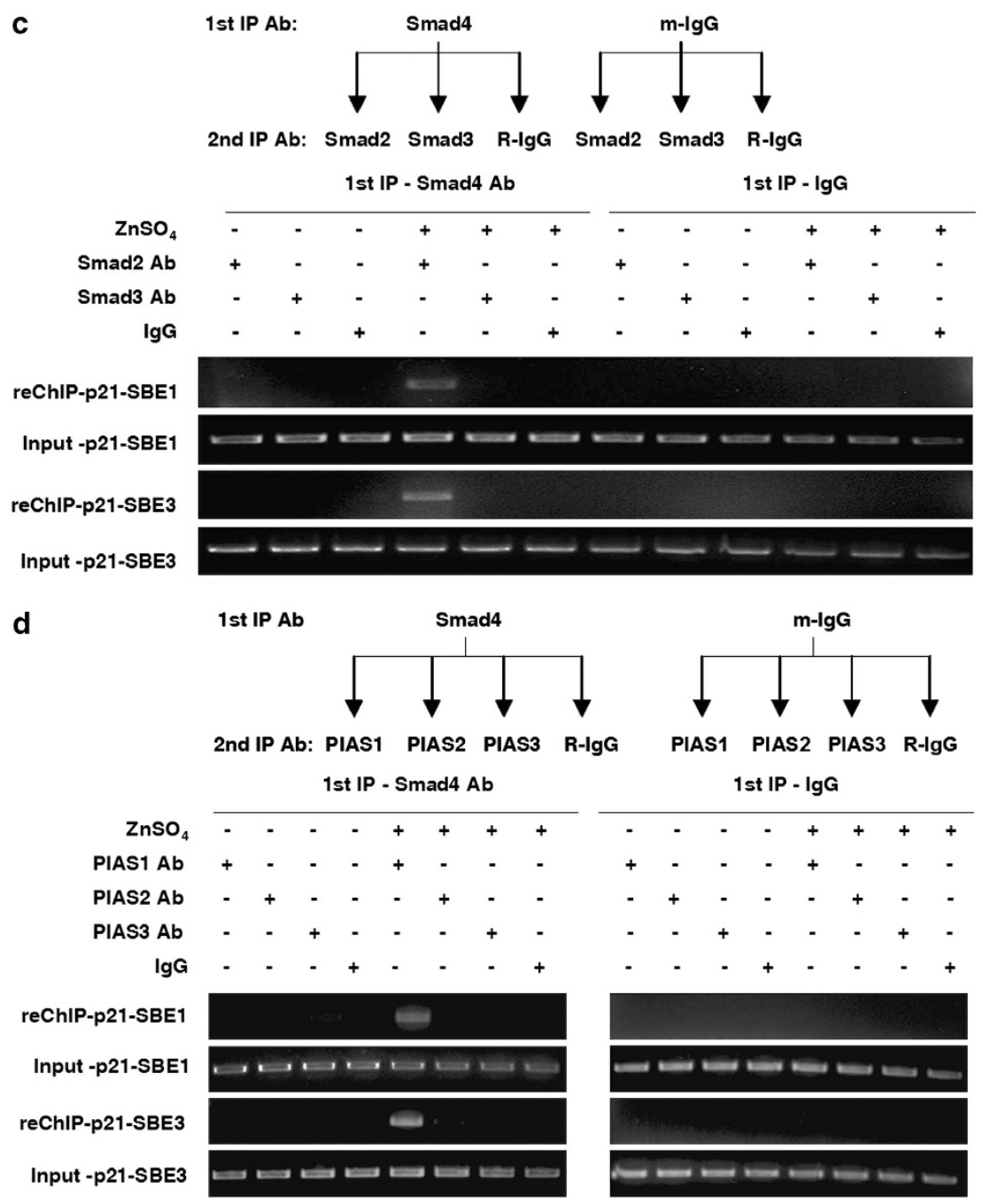

Figure 3 The recruitment of Smad2/4 and PIAS1 complex to the P21WAF1/Cip1 promoter induced by zinc. (a) Schematic diagram of three SBEs of the p21 ${ }^{\text {WAF } 1 / C i p 1}$ promoter. (b) ChIP assays of Smad4 or Smad3 occupancy on the p21 $1^{\text {WAF1/Cip1 }}$ promoter in LNCaP cells with or without zinc treatment. LNCaP cells were used with or without zinc treatment, and anti-Smad4, anti-Smad3 or lgG antibody was added to immunoprecipitate chromatin and the elution was analyzed by p21 promoter-specific primers. (c) Re-ChIP assays of Smad4/Smad2 complex occupancy on the p21 ${ }^{\text {WAF1/Cip1 }}$ promoter in cells with or without zinc treatment. (d) Re-ChIP assays of Smad4/PIAS1 complex occupancy on the p21 ${ }^{\text {WAF } 1 / C i p 1}$ promoter in cells with or without zinc treatment. LNCaP cells were used with or without zinc treatment and mouse anti-Smad4 or IgG antibody was added to immunoprecipitate chromatin. The elution was subjected to a second immunoprecipitation by anti-Smad2, anti-Smad3 or IgG antibody (c), or by anti-PIAS1, PIAS2, PIAS3 or lgG antibody (d). The final elution was analyzed by p21 promoter-specific primers

and two colon cancer (SW480 and HT-29) cell lines were deficient in Smad4 or PIAS1 expression, and were significantly insensitive to zinc-induced apoptosis. The three zincinsensitive cell lines exhibited no p21 WAF1/Cip1 expression response to zinc stimulation (line ' 2 ' in Figures $7 d-f$ ).
However, the overexpression of Smad2, Smad4 and PIAS1 together remarkably increased zinc apoptotic sensitivities in various cancer cells (Figure 7c). The increase of zincinduced p21 WAF1/Cip1 expression (Figure 7d) and Smad4 complex recruited to the $\mathrm{p} 21^{\text {WAF1/Cip } 1}$ promoter (Figure 7e) 

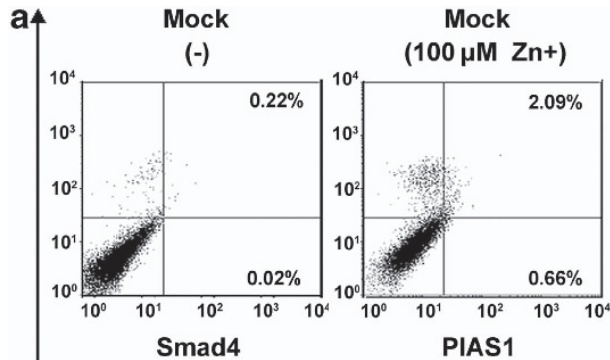

Smad4+PIAS1
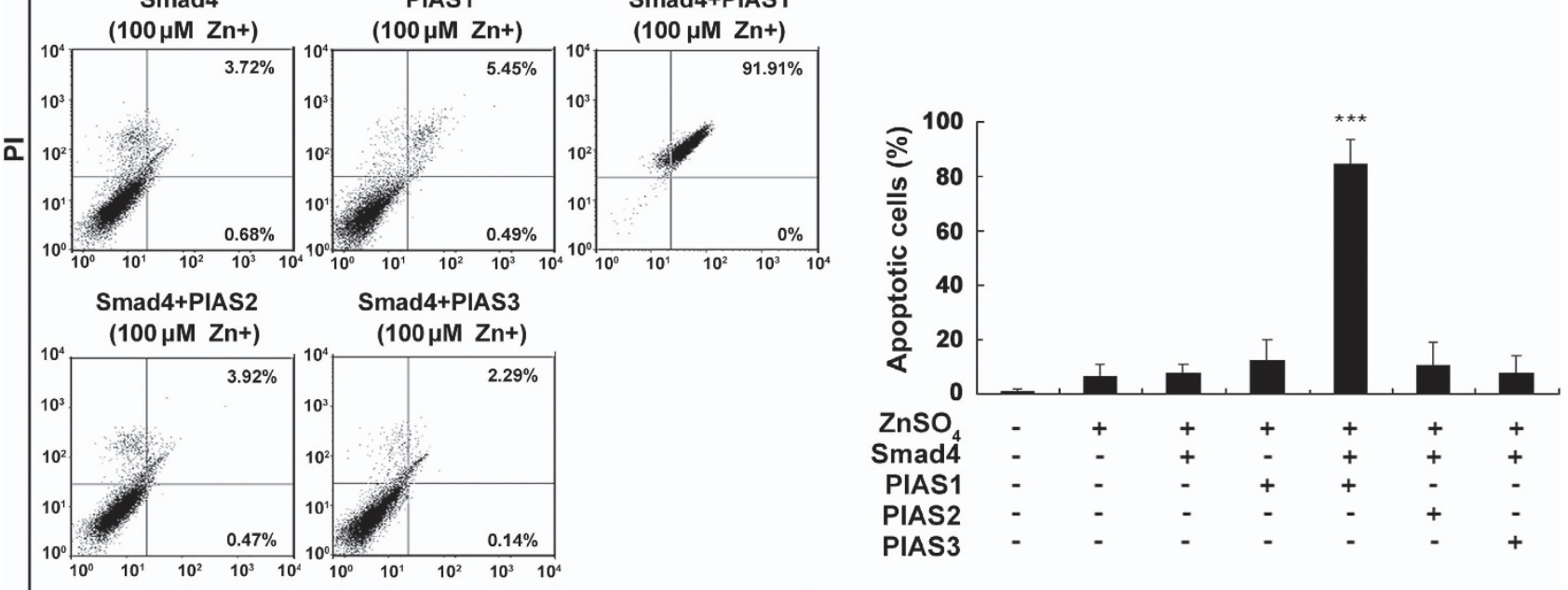

Annexin V
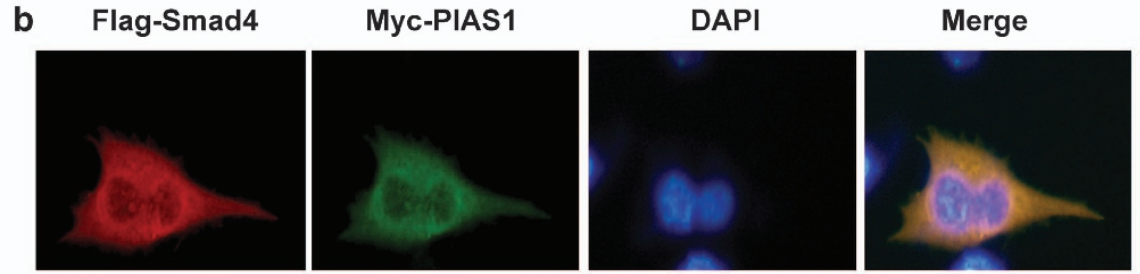

\section{Smad4+PIAS1}

$(-)$
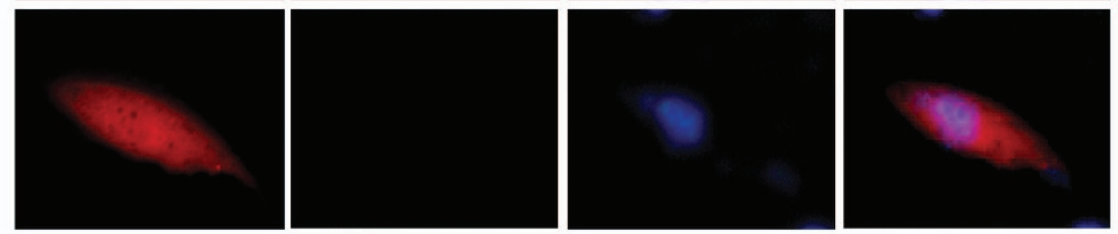

Smad4
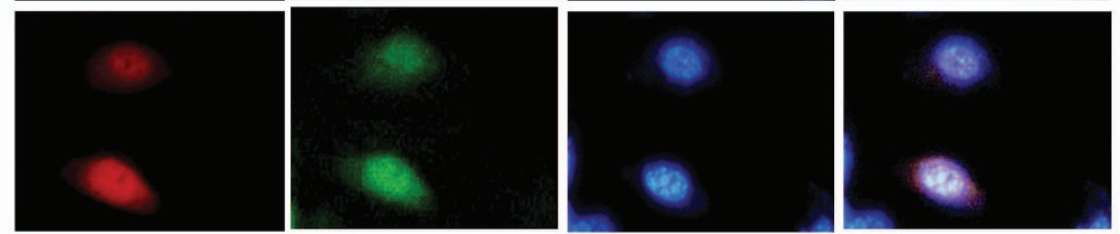

$\left(100 \mu \mathrm{M} \mathrm{ZnSO}_{4}\right)$

Figure 4 The coordination of PIAS1 and Smad4 in zinc-induced LNCaP cell apoptosis and Smad4 nuclear translocation. (a) PIAS1-coordinated Smad4 promotes zincinduced cell apoptosis. LNCaP cells transfected with indicated plasmids were treated with $100 \mu \mathrm{M}$ zinc for $24 \mathrm{~h}$. The apoptotic percentages of cells were measured by flow cytometry. Columns, mean $(n=3)$; bars, S.D. ${ }^{* *} P<0.001$ versus zinc-treated control group (one-way ANOVA). (b) PIAS1 promotes Smad4 translocation into nucleus in zinc-treated cells. LNCaP cells transiently cotransfected with empty vector, Smad4 alone or with PIAS1 for $24 \mathrm{~h}$ were exposed to $100 \mu \mathrm{M}$ zinc. Cells were fixed and stained with anti-Flag (red) and anti-Myc (green) antibodies

attenuated by the overexpression of Smad2/Smad4/PIAS1 could be observed in all six cancer cell lines, especially for the three insensitive cell lines. These data demonstrated the important roles of PIAS1, Smad2, and Smad4 in zincinduced cell death and p21 WAF1/Cip1 transactivation, which were common biological events in different cancer cell lines.

\section{Discussion}

In this study, we have provided compelling evidence that zinc induces apoptosis in prostate cancer with a marked increased in $\mathrm{p} 21^{\text {WAF1/Cip } 1}$ expression, in agreement with previous studies. ${ }^{8-10}$ Exposure to zinc resulted in the induction of 
a

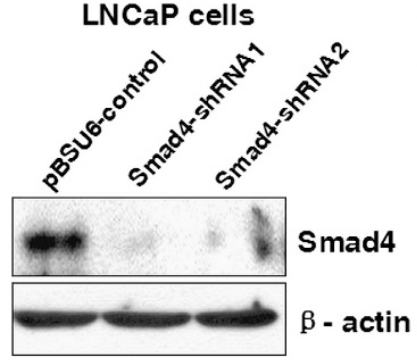

b

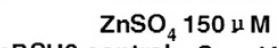

pBSU6-control Smad4-shRNA1

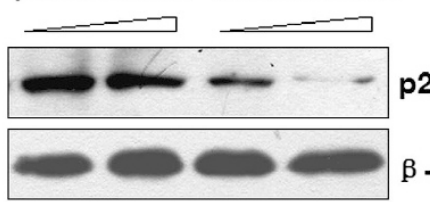

p21

8 - actin

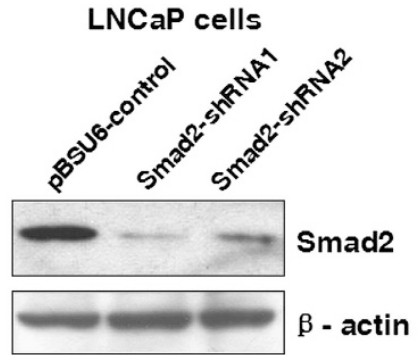

LNCaP cells

$\mathrm{ZnSO}_{4} 150 \mu \mathrm{M}$

pBSU6-control Smad2-shRNA1

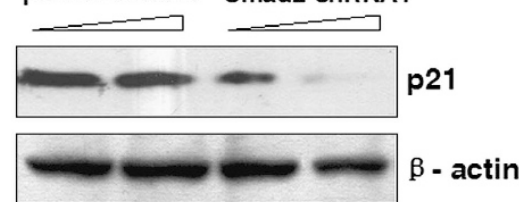

C

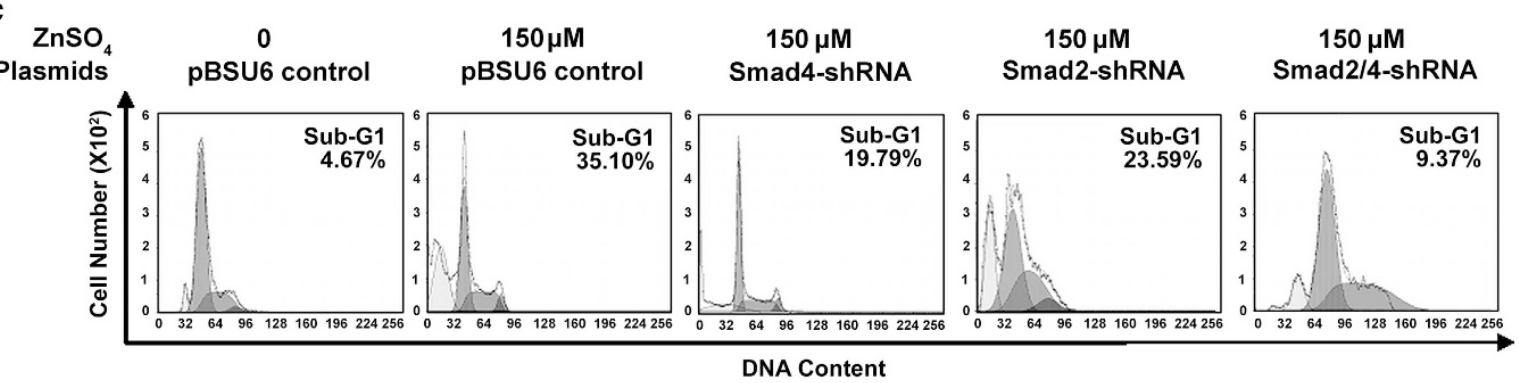

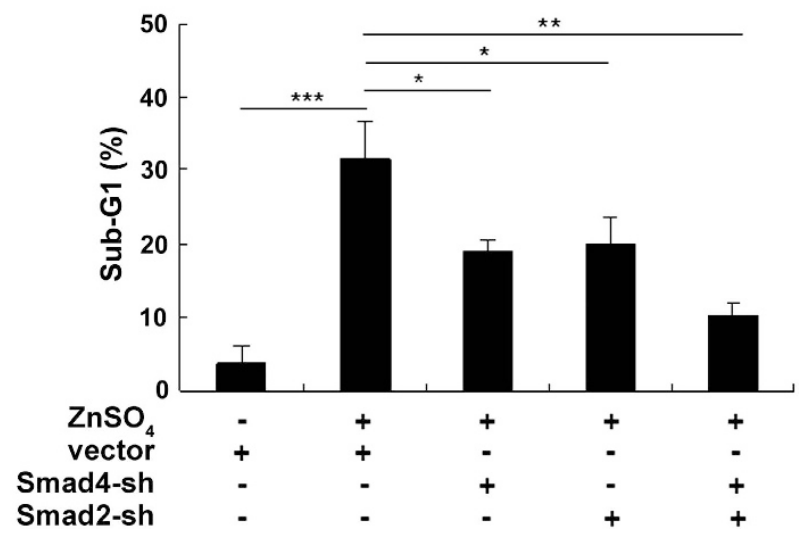

Figure 5 The reduction of LNCaP cell apoptotic sensitivity to zinc with Smad4/Smad2 silencing. (a) LNCaP cells were transfected with two shRNAs targeting the Smad4 or Smad2 gene for $24 \mathrm{~h}$ for immunoblot analysis with the specific antibody against Smad4 or Smad2, using pBSU6 vector group as control. (b) LNCaP transfected with increased amounts of Smad4 or Smad2 plasmids for $24 \mathrm{~h}$ for immunoblot analysis with p21 ${ }^{\mathrm{WAF} 1 / \mathrm{Cip} 1}$ antibody. (c) The percentage of cells of sub-G1 region induced by zinc with Smad2 or Smad4 silence in flow cytometry analysis. Columns, mean $(n=3)$; bars, S.D. ${ }^{*} P<0.05 .{ }^{* \star} P<0.01$. ${ }^{* \star} P<0.001$ (Student's $t$-test)

PIAS1 and Smad2 expression to generate a PIAS1/Smad2/4 complex, which is further recruited to the $\mathrm{p} 21^{\text {WAF } 1 / C i p 1}$ promoter and transactivates the $\mathrm{p} 21^{\text {WAF1/Cip } 1}$ gene, leading to the apoptosis in cancer cells.

Unlike most other cells in which zinc is sequestered into vesicles and organelles, zinc in cytoplasm of prostate cells comprises $\sim 35 \%$ of the total intracellular zinc content. ${ }^{4}$ Zinc concentrations used in this study ranged from 100 to $150 \mu \mathrm{M}$, which were higher than plasma and serum concentrations (15-20 $\mu \mathrm{M})$ and lower than zinc concentrations $(4-7 \mathrm{mM})$ in prostate fluid. $^{4,7}$ In fact, the concentration of fetal bovine serum (FBS) in the culture medium is an important factor affecting the zinc concentration to induce apoptosis, which is demonstrated to range from $15 \mu \mathrm{M}$ in the medium without FBS to $150 \mu \mathrm{M}$ in the medium with $10 \%$ FBS supplements. ${ }^{38-40}$ Using the regular cell culture condition with $10 \%$ FBS, we observed that moderate zinc concentration $(150 \mu \mathrm{M})$ induces significant apoptosis by promoting p $21^{\text {WAF1/Cip } 1}$ expression in both LNCaP and PC3 cells. Moreover, zinc-induced cell apoptosis or p21 WAF1/Cip1 augment were blocked by the 
a

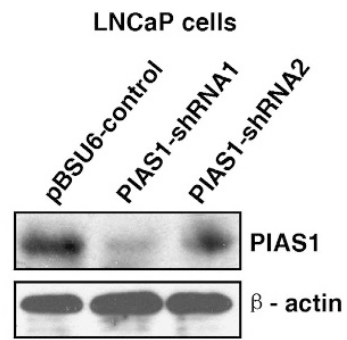

b

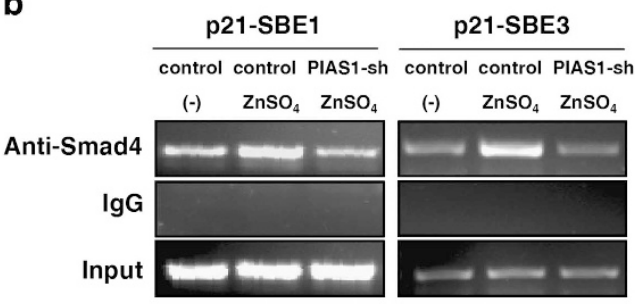

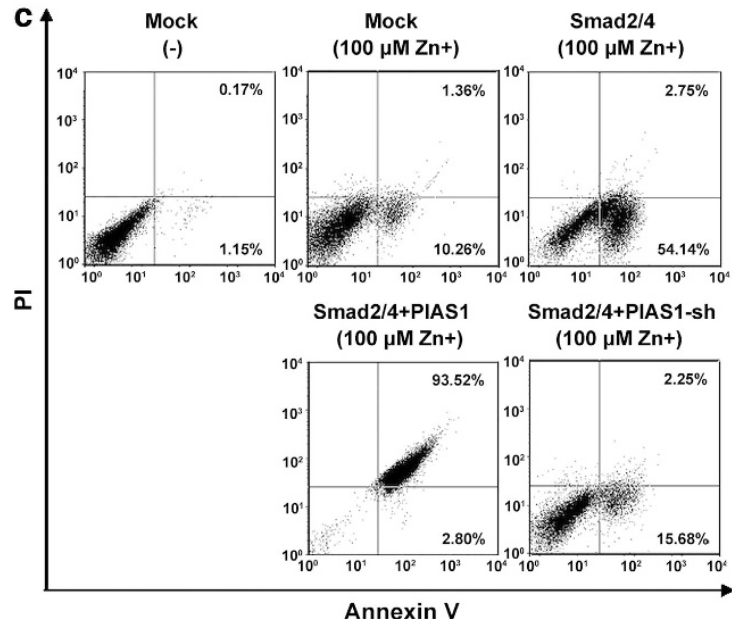

Annexin V

d

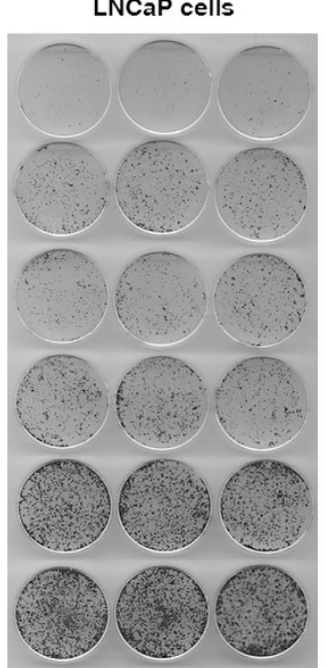

Mock

$(150 \mu \mathrm{M} \mathrm{Zn+)}$

Smad2-shRNA

$(150 \mu M \mathrm{Zn+})$

Smad4-shRNA

$(150 \mu M \mathrm{Zn}+)$

PIAS1-shRNA

(150 $\mu M \mathrm{Zn+})$

$(150 \mu \mathrm{M} \mathrm{Zn+)}$

Smad2/4/PIAS1-shRNA

$(150 \mu M \mathrm{Zn}+)$
Smad2/4-shRNA

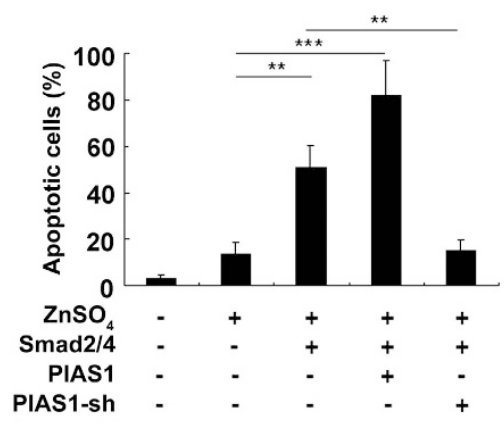

Figure 6 The essential roles of PIAS1 for Smad4-mediated p21 ${ }^{\text {WAF1/Cip1 }}$ promoter binding, cell apoptosis and inhibition of proliferation. (a) LNCaP cells were transfected with PIAS1-shRNAs for immunoblot analysis with PIAS1 antibody. (b) The increased binding of Smad4 to SBE1 and SBE3 regions in the p21 $1^{\text {WAF1/Cip1 }}$ promoter was reversible by PIAS1-shRNA. LNCaP cells transfected with PIAS1-shRNA1 or the control vector were treated with $150 \mu \mathrm{M} \mathrm{ZnSO}{ }_{4}$ for $24 \mathrm{~h}$. Cross-linked chromatin complexes were immunoprecipitated with anti-Smad4 or IgG antibody. Co-precipitated DNA sequences were amplified using specific primers spanning the SBE1 and SBE3 in the p21 WAF1/Cip1 promoter. (c) LNCaP cells were transiently cotransfected with plasmids as indicated, and then treated with $125 \mu \mathrm{M} \mathrm{ZnSO4}$ for $24 \mathrm{~h}$. The apoptotic percentages of cells were measured by flow cytometry. Columns, mean $(n=3)$; bars, S.D. ${ }^{* \star} P<0.01 .{ }^{* \star} P<0.001$ (Student's t-test). (d) LNCaP cells were transfected with Smad4-shRNA, Smad2shRNA, or PIAS1-shRNA alone or together, and then cultured in the $\mathrm{T}$ medium containing $150 \mu \mathrm{M} \mathrm{ZnSO}$ for 12 days. Colonies containing more than 50 cells were counted. Columns, mean $(n=3)$; bars, S.D. ${ }^{\star} P<0.05$. ${ }^{* *} P<0.01 .{ }^{* * *} P<0.001$. All versus mock-transfected zinc-treated control group (Student's $t$-test)

chelating agents, which provided the evidence for the link between the reduction of intracellular zinc concentration and the development of prostate cancer.

The p21 WAF1/Cip1 gene has a key role in cell cycle arrest at the G1 stage by inhibiting CDKs, and was identified as an important transcriptional target of p53 and TGF- $\beta$-Smad4 pathways. ${ }^{9,11-15}$ In this study, we showed that the Smad pathway but not the p53 pathway is involved in the zincinduced apoptosis, in line with other reports..$^{8,9,28,29}$ Our results demonstrate that zinc induces apoptosis in LNCaP (p53-positive), PC3 (p53-null) cells, indicating that zincinduced apoptosis is not associated with p53 status, 
a

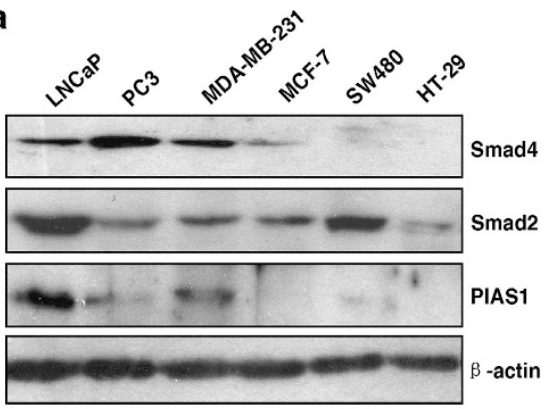

b

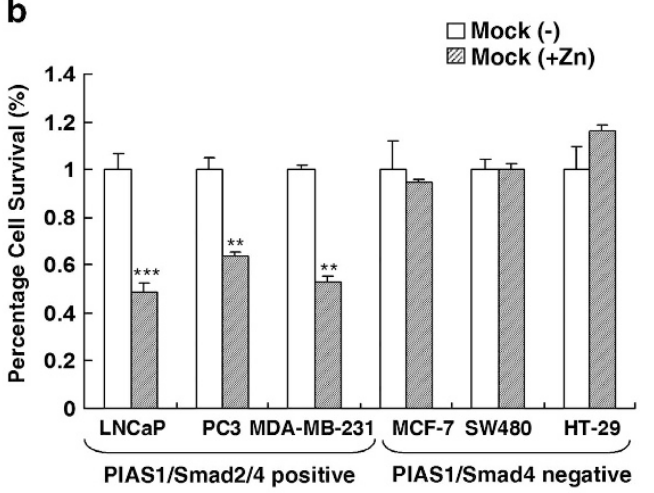

C
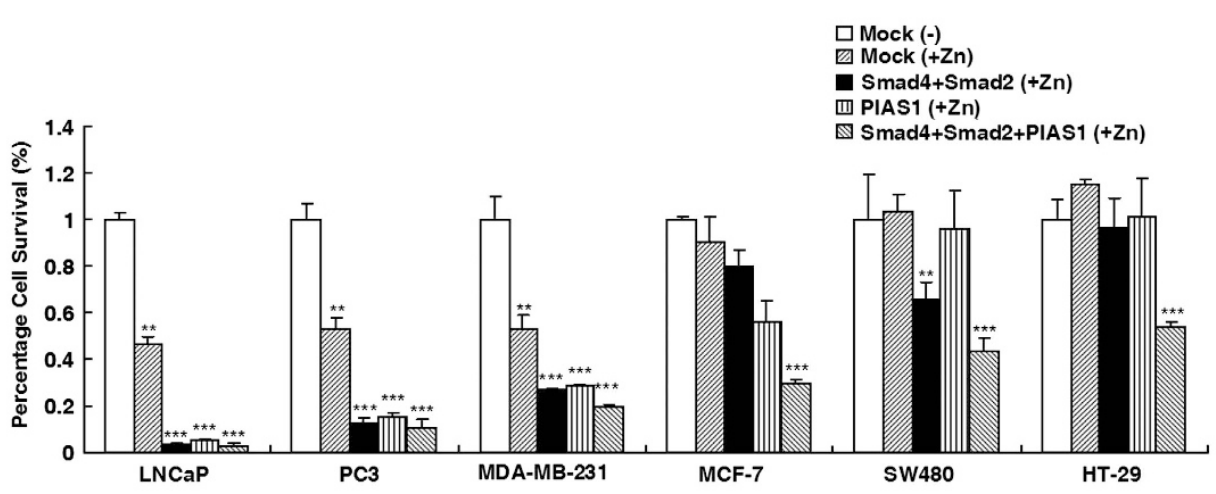

d

1 Mock (-)

2 Mock (+Zn)

3 Smad4+Smad2+PIAS1 (+Zn)

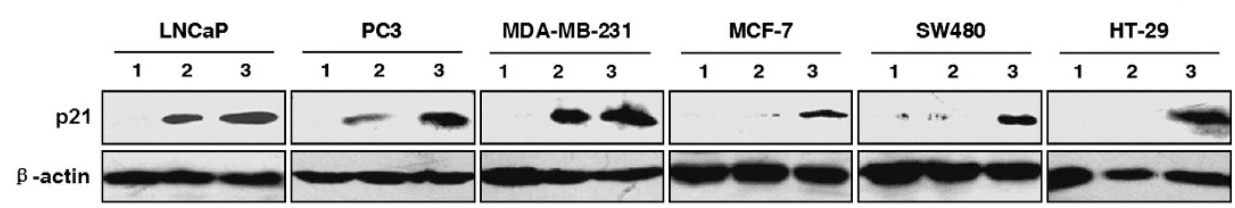

e

1 Mock (-)

2 Mock $(+Z n)$

3 Smad4+Smad2+PIAS1 (+Zn)
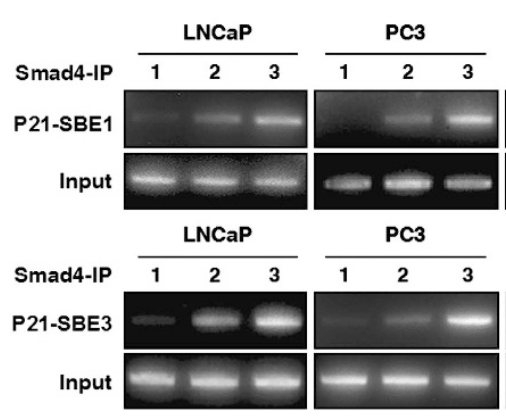

\begin{tabular}{ll} 
MDA-MB-231 \\
\hline 123
\end{tabular}

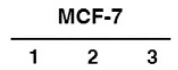

\begin{tabular}{lll} 
& & \\
\hline 1 & 2 & 3
\end{tabular}
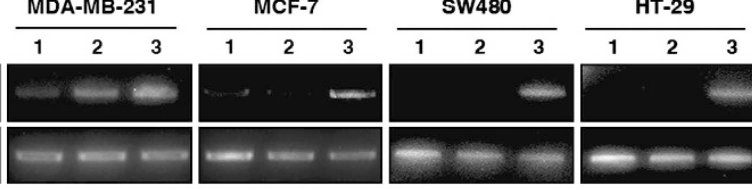

MDA-MB-231

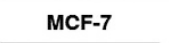

sw480
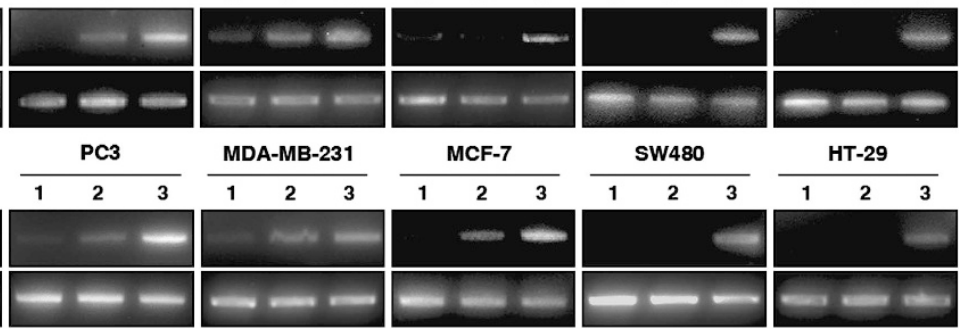

Figure 7 The universal association of the expression levels of Smad2, Smad4 and PIAS1 with the apoptotic sensitivities in various cancer cells. (a) Immunoblot analysis of Smad4, Smad2 and PIAS1 expression in different cancer cell lines including human prostate cancer cell lines LNCaP and PC3, breast cancer cell lines MDA-MB-231 and MCF-7, and colon cancer cell lines SW480 and HT-29. (b) Cell survival profile in response to $150 \mu \mathrm{M}$ zinc treatment for $24 \mathrm{~h}$ in LNCaP, PC3, MDA-MB-231, MCF-7, SW480, and HT-29 cells. Columns, mean $(n=3)$; bars, S.D. ${ }^{\star \star} P<0.01 .{ }^{* \star} P<0.001$, versus mock-transfected group in the absence of zinc for each cell line (Student's $t$-test). (c) Zinc-induced cell survival inhibition attenuated by the overexpression of Smad2/Smad4 and PIAS1 alone or together. Percentage of surviving cells transfected with empty vector or Smad4/Smad2 and/or PIAS1 plasmids response to zinc treatment is normalized against the cells transfected with the empty vector without zinc treatment for each cell line. Columns, mean $(n=3)$; bars, S.D. ${ }^{* *} P<0.01$. ${ }^{* \star *} P<0.001$ (one-way ANOVA). (d) Attenuation of p21 WAF1/Cip1 expression by the overexpression of Smad2/Smad4 and PIAS1. Percentage of surviving cells transfected with empty vector or Smad4/Smad2 and/or PIAS1 plasmids response to $150 \mu \mathrm{M} \mathrm{ZnSO} \mathrm{Z}_{4}$ for $24 \mathrm{~h}$. The p21 WAF1/Cip1 levels were examined by immunoblot analysis with either $\mathrm{p} 21^{\text {WAF1/Cip1 }}$ or $\beta$-actin antibody. (e) Attenuation of zinc-induced Smad4 occupancy on the p21 WAF1/Cip1 promoter by the overexpression of Smad2/Smad4 and PIAS1. ChIP assays of Smad4 occupancy on the p21 ${ }^{\text {WAF1/Cip1 }}$ promoter were performed with anti-Smad4 or IgG antibody and then analyzed by p21 promoter-specific primers 
consistent with other studies that zinc leads to IIC9 cell death in a p53-independent manner. ${ }^{41}$ Furthermore, in our comparative analysis of reporters, p21P $\Delta$ p53-luc lacking p53binding sequence, as with p21P-luc or Smad downstream $4{ }^{*} \mathrm{SBE}-$ luc reporter, show significant inductions by zinc, but not the pp53-TA-luc reporter that is only activated by $p 53$, providing evidence that zinc treatment induces p21 WAF1/Cip 1 transactivation in a Smad-dependent and p53-independent manner.

Smad2 and Smad3 are members of R-Smads, which are activated in response to TGF- $\beta$. These proteins associate with receptor kinases and are phosphorylated at an SSXS motif of C-terminus, and then typically bind to the common mediator Smad4. However, Smad2 and Smad3 exhibit different responses to different factors. For example, IGF-I selectively inhibits the TGF- $\beta$-triggered activation of Smad3 but not Smad2. ${ }^{42}$ Our findings reveal that zinc activates Smad2 expression but not Smad3. In particular, the critical suppressor roles of Smad2 have been sufficiently demonstrated in multiple cancers, including skin cancer development and malignant transformation of prostate cancer or breast cancer bone metastasis, whereas Smad3 has inactivating or opposite roles in these processes. ${ }^{19,43,44}$ A recent study demonstrates Smad2 as a critical mediator of TGF- $\beta$-induced apoptosis and gene expression by the results that Smad2 silencing alone causes malignant transformation of prostate cancer NRP-152 cells in athymic mice, whereas Smad3 silencing alone did not induce tumors. ${ }^{19}$ In this study, the important roles of the Smad4/pSmad2 complex in zinc-induced apoptosis is further proved. First, Smad2, but not Smad3, is dramatically increased in response to zinc, and is involved in the formation of a Smad4/Smad2/PIAS1 complex. Second, with zinc stimulation, PIAS1 exhibits the interaction only with Smad2, but not with Smad3 (Figures 1d and e). Moreover, the activated Smad2/4/PIAS1 complex is capable of translocating to the nucleus and being present at the SBE1 and SBE3 regions of the $\mathrm{p} 21^{\text {WAF1/Cip } 1}$ promoter to activate the p21 ${ }^{\text {WAF1/Cip } 1}$ gene (Figure $3 \mathrm{c}$ ). Thus, our findings provided the possible mechanisms for the repair of TGF- $\beta /$ Smad4 proliferation-inhibition signaling in cancer cells by zinc treatment to restore Smad2 expression and activation.

Smad4 has a central role in TGF- $\beta$ signaling and is associated with the progression of many tumors. A significantly decreased nuclear Smad4 is always shown in many kinds of cancers, suggesting the inactivation of the Smad pathway. ${ }^{13,20}$ Here, we demonstrate the critical roles of Smad4 in zinc-induced apoptosis. Although there are no significant changes for the expression levels in response to zinc treatment, Smad4 exhibits increased binding capacity with phosphorylated Smad2 and PIAS1, significant nuclear translocation, and functionally direct binding to SBE1 and SBE3 regions of the $\mathrm{p} 21^{\text {WAF1/Cip } 1}$ promoter. The knockdown of endogenous Smad4 in LNCaP cells resulted in apparent reduction of cell apoptotic sensitivity to zinc and the attenuation of zinc-induced p21 WAF1/Cip1 transactivation and apoptosis in zinc-insensitive cell lines by the overexpression of Smad2/Smad4/PIAS1, suggesting the pivotal mediator roles of Smad4 in the zinc-activated Smad pathway.

In this study, we have identified a novel role of PIAS1 in zincinduced apoptosis. The PIAS family has been proposed to interact with many transcription factors, acting as a transcriptional co-regulator. ${ }^{21-26}$ The substantially reduced expression of PIAS1 is reported to be associated with colon cancer, gastric cancer, and hormone-refractory prostate cancers. ${ }^{27-30}$ Previous reports suggested PIAS1 physically interacts with Smad4 and enhances the Smad4-dependent transcriptional activation of TGF- $\beta$ signaling, whereas PIAS3 preferred to activate Smad3. ${ }^{21,23}$ Here, we elucidated that PIAS1 is the only member of the PIAS family involved in zinc-induced Smad4 pathway activation. PIAS1 contains conserved SP-RING zincfinger ring domains as with other PIAS proteins, but several unique sequences are distinguished from other PIAS numbers. Interestingly, zinc stimulation strongly enhanced the PIAS1 interaction with the Smad2/4 complex, with the disassociation of the original PIAS1/Smad3 complex, suggesting the different roles of PIAS1 in Smad3 and Smad2 regulation. In addition, PIAS1 obviously promotes zinc-induced Smad4 nuclear translocation and dramatically increases Smad4 recruitment on the p21 WAF1/Cip1 promoter, to further promote Smad2/4 mediated proliferation inhibition. Moreover, PIAS1 contributes to zinc apoptotic sensitivity in all various cancer cells. All our observations supported that PIAS1, the expression of which is restored by zinc, has essential biological regulatory roles in the zinc-induced cell death.

In conclusion, this study demonstrates for the first time that PIAS1, a member of PIAS protein family, augments the transcriptional activity of the Smad2/Smad4 protein complex not only in zinc-induced LNCaP cell apoptosis, but also in various cancer cells. As the deficiency or suppression of Smad2/3/4 is always exhibited in prostate cancer and other cancers, the activation of the Smad pathway is a critical strategy to restore the apoptotic mechanism for cancer therapy. Based on our findings, we provided an overview of possible mechanisms by which zinc induces apoptosis in LNCaP cells in Figure 8. Furthermore, our data provide a novel target for zinc by triggering the Smad2/4/PIAS1 complex to activate the p21 WAF1/Cip1 gene, and to further promote apoptosis in cancers, and which may provide interesting avenues for novel therapeutic interventions.

\section{Materials and Methods}

DNA plasmids. pRK4-Flag-Smad4 was kindly provided by Dr. Hsiu-Ming Shih (Taipei, China). ${ }^{45}$ The pcDNA3-FLAG-Smad2 was constructed by subcloning the full-length Smad2 cDNAs into the pcDNA3 vector (Invitrogen, Carlsbad, CA, USA) in-frame with an N-terminal flag epitope tag. The pGADT7-PIAS1, pGADT7PIASx $\beta$ were kindly provided by Dr. Edward E. Schmidt (Bozeman, USA) and PIAS3 by Ehud Razin (Jerusalem, Israel), ${ }^{46,47}$ and PIAS family genes were subcloned into pCMV-myc vector (Clontech, Mountain View, CA, USA). The p21 $1^{\text {WAF } 1 / C i p 1}$ promoter reporter constructs, including one 2.4-kb major portion of the $\mathrm{p} 21^{\text {WAF } 1 / \text { Cip } 1}$ proximal promoter reporter of p21P-luc, and another $2.15 \mathrm{~kb}$ of p53-binding site deletion reporter of p21P $\Delta$ p53-luc, were gifts from Xiao Fang Wang (Duke University, USA). ${ }^{48}$ The pp53-TA-luc containing just p53-binding sites in the $\mathrm{p} 21^{\mathrm{WAF} / \mathrm{C} \text { ip } 1}$ proximal promoter was obtained from BD Clontech. The $4^{*}$ SBE-Luc reporter containing a synthetic promoter composed of four repeated SBEs, was kindly provided by Dr. Yoichi Kato (Florida State University, USA). ${ }^{49}$ The small hairpin (sh) RNAs for PIAS1, Smad2 or Smad4 were generated as described previously. ${ }^{50}$

Cell culture, transient transfection and luciferase assays. The human prostate cancer cell line, LNCaP, was cultured in $\mathrm{T}$ medium (GIBCO, Grand Island, NY, USA; custom formula \# 02-0056DJ, 80\% DMEM, $20 \% \mathrm{~F} 12 \mathrm{~K}, 3 \mathrm{~g} / \mathrm{l} \mathrm{NaHCO}_{3}, 5 \mu \mathrm{g} / \mathrm{ml}$ insulin, $13.6 \mathrm{pg} / \mathrm{ml}$ triiodothyronine, $5 \mu \mathrm{g} / \mathrm{ml}$ 


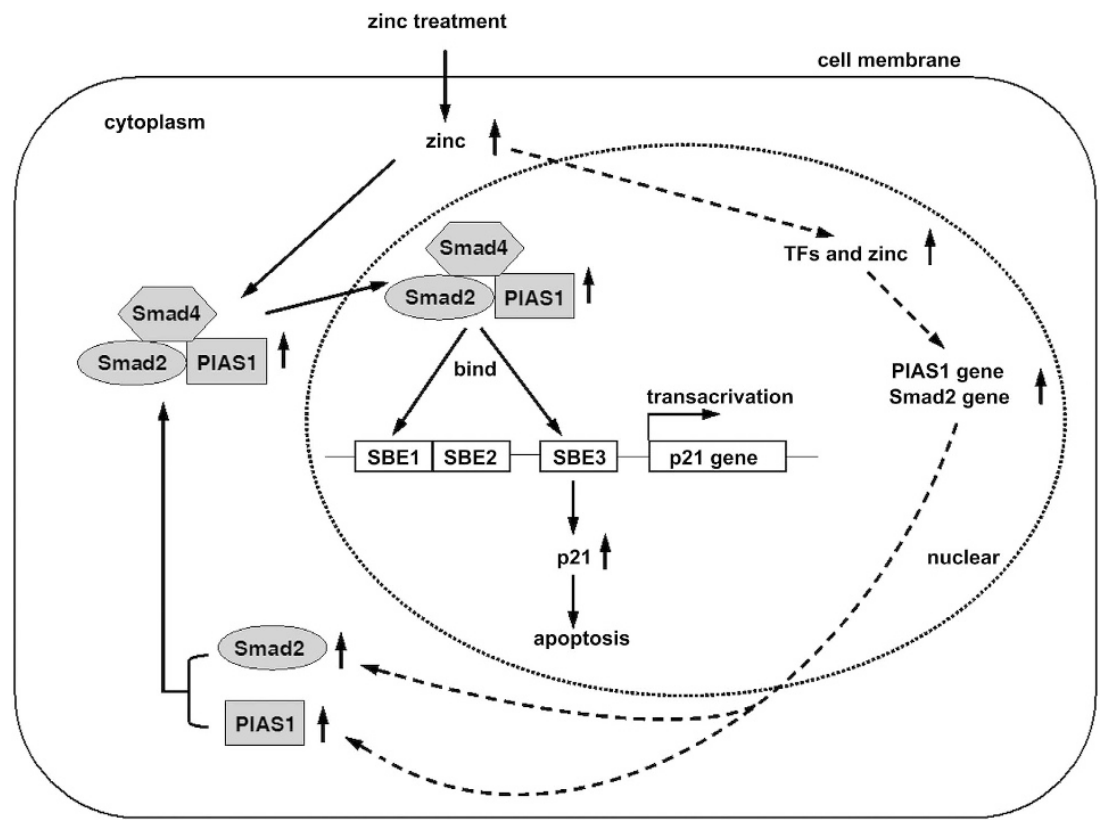

Figure 8 The model for zinc-induced apoptosis in cancer cells. Zinc increases the expression of Smad2 and PIAS1, and then promotes the formation of the Smad4/ Smad2/PIAS1 complex and its subsequent nuclear translocation. In the nucleus, zinc recruits Smad4/Smad2/PIAS1 complex binding onto SBE1 and SBE3 regions of the $\mathrm{p} 21^{\mathrm{WAF} 1 / \mathrm{Cip} 1}$ promoter, to upregulate the transcription and expression of $\mathrm{p} 21$, which facilitates the cell apoptosis as a proapoptotic protein

transferring, $0.25 \mu \mathrm{g} / \mathrm{ml}$ biotin, $25 \mu \mathrm{g} / \mathrm{ml}$ adenine) plus $10 \%$ FBS. The prostate cancer cell line, PC3, breast cancer cell lines, MCF-7 and MDA-MB-231 and colon cancer cell lines, SW480 and HT-29, were maintained in DMEM medium with $10 \%$ FBS. Transient transfections were carried out using Lipofectamine 2000 (Invitrogen) following the manufacturer's protocol. Cells were seeded into 48well plates for $16 \mathrm{~h}$ and cotransfected with each of four reporter plasmids $100 \mathrm{ng}$, including two p21 ${ }^{\text {WAF1/Cip } 1}$ promoter reporters, p21P-luc and p21P $\Delta$ p53-luc, Smad pathway reporter $4^{*}$ SBE-luc, and P53 pathway reporter pp53-TA-luc, in the presence of Renilla luciferase control pREP7 vector $25 \mathrm{ng}$, and then treated with zinc sulfate ranging from 0 to $150 \mu \mathrm{M}$ for $8 \mathrm{~h}$. Firefly luciferase activities were measured by using the dual-luciferase reporter assay system (Promega, Madison, WI, USA) and the ratio of firefly luciferase activity to Renilla luciferase activity was calculated as relative luciferase activity.

Immunoprecipitation and immunoblot analysis. LNCaP cells were treated with zinc sulfate for $24 \mathrm{~h}$ and cross-linked with $1-2 \mathrm{mM}$ dithio-bis succinimidyl propionate for $30 \mathrm{~min}$. Pre-cleared lysates were then incubated with pre-equilibrated protein-A-Sepharose beads with either normal rabbit IgG or PIAS1 polyclonal antibody (Bioworld, Louis Park, MN, USA), or with either normal mouse IgG or Smad4 monoclonal antibody (Santa Cruz Biotechnology, Santa Cruz, CA, USA) at $4{ }^{\circ} \mathrm{C}$ for $3 \mathrm{~h}$. Eluted proteins were analyzed by immunoblots using Smad4, Smad2/3, PIAS1, PIAS2, PIAS3 (Bioworld), and phosphorylated Smad2 (pSmad2) (Santa Cruz) antibodies at the appropriate dilutions.

Immunofluorescence. LNCaP cells were transfected with Smad4 and/or PIAS1 plasmids and then treated with zinc sulfate for $24 \mathrm{~h}$ and then fixed with $3 \%$ formaldehyde for $30 \mathrm{~min}$. After being blocked in PBS-BSA buffer for $15 \mathrm{~min}$, the cells were incubated with monoclonal Smad4 and polyclonal PIAS1 antibodies for $2 \mathrm{~h}$, followed by incubation with fluorophore-conjugated secondary antibodies (Proteintech Group, Chicago, IL, USA). DAPI staining for 1 min was carried out after secondary antibody incubation.

Sub-G1 analysis, apoptosis assay and flow cytometry analysis. Cells were transfected with the plasmids and then treated with zinc sulfate for $24 \mathrm{~h}$. The propidium iodide (PI)-Hypotonic lysis buffer was added for a 30-min incubation, and then the cells were analyzed by flow cytometry for sub-G1 analysis as described previously. ${ }^{51}$ Apoptosis kits (Santa Cruz) containing Annexin-V-FITC and PI were used to determine cell apoptosis according to the manufacturer's instructions.
ChIP and Re-ChIP assays. LNCaP cells were treated with zinc sulfate for $24 \mathrm{~h}$, and then treated with $2 \%$ formaldehyde to crosslink protein-DNA. After the cells were lysed by a nucleus lysis buffer, the lysates were sonicated. Sonicated lysates were centrifuged at 14000 r.p.m. at $4^{\circ} \mathrm{C}$ for $15 \mathrm{~min}$ to get rid of insoluble fractions. An aliquot of the soluble fraction was set aside and designated as input fraction. The remaining fraction was immunoprecipitated with anti-Smad4 antibody or mouse IgG (Santa Cruz). After immunoprecipitation, the precipitated complexes were collected by adding protein G-agarose beads. For re-ChIP, the immuno-complexes were eluted with re-ChIP elution buffer (10 mM DTT), and the supernatant was diluted 1:40 in ChIP dilution buffer. Antibodies against the second proteins of interest were added, incubated at $4{ }^{\circ} \mathrm{C}$ overnight, and collected by incubating with protein $\mathrm{A}$ beads at $4{ }^{\circ} \mathrm{C}$ for $3 \mathrm{~h}$. In both ChIP and re-ChIP assays, the immuno-complexes were eluted from the beads through incubation with $10 \times$ bead volume of elution buffer (1\% SDS, $0.1 \mathrm{M}$ $\mathrm{NaHCO}_{3}$ ). Following elution and cross-linking reservation, DNA was recovered by proteinase $\mathrm{K}$ digestion, phenol/chloroform extraction and ethanol precipitation. Samples were analyzed by PCR. ChIP primer sequences of SBE1, SBE2, SBE3, and TATA regions in the p21 ${ }^{\text {WAF1/Cip1 }}$ promoter are described previously. ${ }^{15,52}$

Colony formation assay. About $2000 \mathrm{LNCaP}$ cells were transfected with shRNA-Smad4, shRNA-Smad2, and/or shRNA-PIAS1 for $24 \mathrm{~h}$ and then $150 \mu \mathrm{M}$ zinc was supplemented into the medium. After 12 days culture, the cells were stained with $0.05 \%$ crystal violet to assess colony staining. Colonies containing more than 50 cells were counted.

Assessment of cell survival by WST-1 assay. Cell viability of LNCaP, PC3, MDA-MB-231, MCF-7, SW480 and HT-29 cells was determined using the WST-1 assay kit (Roche, Indianapolis, IN, USA) in accordance with the manufacturer's recommended protocol. In brief, after zinc treatment for $24 \mathrm{~h}$, the medium was then replaced with fresh growth medium supplemented with $10 \%$ WST-1 reagent. This was followed by an additional incubation at $37^{\circ} \mathrm{C}$ for $30-60 \mathrm{~min}$. Changes in cell viability were reflected by changes in optical density detected at $450 \mathrm{~nm}$, which was measured using a spectrophotometer microplate reader (SpectraMax 340; Molecular Devices, Sunnyvale, CA, USA).

Statistical analysis. All results are presented as the mean \pm S.D. Student's $t$-test was used to compare means of two independent groups. One-way ANOVA 
was applied to analyze the difference of means of more than two groups. Statistical significance was assumed for a two-tailed $P<0.05$ using SPSS 17.0 (Chicago, IL, USA).

\section{Conflict of Interest}

The authors declare no conflict of interest.

Acknowledgements. This study was supported by Ministry of Science and Technology (No. 2010DFA31430), Ministry of Education of China (NCET-10-0316; 10SSXT147), Jilin Provincial Science \& Technology Department (20130521010JH), Changchun Science \& Technology Department (No. 2011114-11GH29) and the Program for Introducing Talents to Universities (No. B07017). We thank Mr. Michael Hoyt and Professor Zijie Sun (Stanford University), who critically read and revised our manuscript.

1. Siegel R, DeSantis $C$, Virgo K, Stein K, Mariotto $A$, Smith $T$ et al. Cancer treatment and survivorship statistics, 2012. CA Cancer J Clin 2012; 62: 220-241.

2. Sim HG, Cheng CW. Changing demography of prostate cancer in Asia. Eur J Cancer 2005; 41: 834-845

3. Franklin RB, Costello LC. Zinc as an anti-tumor agent in prostate cancer and in other cancers. Arch Biochem Biophys 2007; 463: 211-217.

4. Costello LC, Franklin RB, Feng P, Tan M, Bagasra O. Zinc and prostate cancer: a critical scientific, medical, and public interest issue (United States). Cancer Causes Control 2005; 16: $901-915$

5. Huang L, Kirschke CP, Zhang Y. Decreased intracellular zinc in human tumorigenic prostate epithelial cells: a possible role in prostate cancer progression. Cancer Cell Int 2006; 6: 10.

6. Johnson LA, Kanak MA, Kajdacsy-Balla A, Pestaner JP, Bagasra O. Differential zinc accumulation and expression of human zinc transporter 1 (hZIP1) in prostate glands. Methods 2010; 52: 316-321.

7. Kelleher SL, McCormick NH, Velasquez V, Lopez V. Zinc in specialized secretory tissues: roles in the pancreas, prostate, and mammary gland. Adv Nutr 2011; 2: 101-111.

8. Feng P, Li T, Guan Z, Franklin RB, Costello LC. The involvement of Bax in zinc-induced mitochondrial apoptogenesis in malignant prostate cells. Mol Cancer 2008; 7: 25.

9. Feng P, Li TL, Guan ZX, Franklin RB, Costello LC. Direct effect of zinc on mitochondrial apoptogenesis in prostate cells. Prostate 2002; 52: 311-318.

10. Liang JY, Liu YY, Zou J, Franklin RB, Costello LC, Feng P. Inhibitory effect of zinc on human prostatic carcinoma cell growth. Prostate 1999; 40: 200-207.

11. Boulaire J, Fotedar A, Fotedar R. The functions of the cdk-cyclin kinase inhibitor p21WAF1. Pathol Biol (Paris) 2000; 48: 190-202.

12. Chi XZ, Yang JO, Lee KY, Ito K, Sakakura C, Li QL et al. RUNX3 suppresses gastric epithelial cell growth by inducing p21(WAF1/Cip1) expression in cooperation with transforming growth factor \{beta\}-activated SMAD. Mol Cell Biol 2005; 25: 8097-8107.

13. Derynck R, Akhurst RJ, Balmain A. TGF-beta signaling in tumor suppression and cance progression. Nat Genet 2001; 29: 117-129.

14. Pardali K, Kowanetz M, Heldin CH, Moustakas A. Smad pathway-specific transcriptiona regulation of the cell cycle inhibitor p21(WAF1/Cip1). J Cell Physiol 2005; 204: 260-272.

15. Saramaki A, Banwell CM, Campbell MJ, Carlberg C. Regulation of the human p21(waf1/ cip1) gene promoter via multiple binding sites for $\mathrm{p} 53$ and the vitamin D3 receptor. Nucleic Acids Res 2006; 34: 543-554.

16. de Caestecker MP, Piek E, Roberts AB. Role of transforming growth factor-beta signaling in cancer. J Natl Cancer Inst 2000; 92: 1388-1402.

17. Perttu MC, Martikainen PM, Huhtala HS, Blauer M, Tammela TL, Tuohimaa PJ et al. Altered levels of Smad2 and Smad4 are associated with human prostate carcinogenesis. Prostate Cancer Prostatic Dis 2006; 9: 185-189.

18. Tu WH, Thomas TZ, Masumori N, Bhowmick NA, Gorska AE, Shyr Y et al. The loss of TGFbeta signaling promotes prostate cancer metastasis. Neoplasia 2003; 5: 267-277.

19. Yang J, Wahdan-Alaswad R, Danielpour D. Critical role of Smad2 in tumor suppression and transforming growth factor-beta-induced apoptosis of prostate epithelial cells. Cancer Res 2009; 69: 2185-2190.

20. Yang G, Yang X. Smad4-mediated TGF-beta signaling in tumorigenesis. Int J Biol Sci 2010; 6: 1-8.

21. Liang M, Melchior F, Feng XH, Lin X. Regulation of Smad4 sumoylation and transforming growth factor-beta signaling by protein inhibitor of activated STAT1. J Biol Chem 2004; 279: 22857-22865.

22. Long J, Matsuura I, He D, Wang G, Shuai K, Liu F. Repression of Smad transcriptional activity by PIASy, an inhibitor of activated STAT. Proc Natl Acad Sci USA 2003; 100: 9791-9796.

23. Long J, Wang G, Matsuura I, He D, Liu F. Activation of Smad transcriptional activity by protein inhibitor of activated STAT3 (PIAS3). Proc Natl Acad Sci USA 2004; 101: 99-104.

24. Gross M, Liu B, Tan J, French FS, Carey M, Shuai K. Distinct effects of PIAS proteins on androgen-mediated gene activation in prostate cancer cells. Oncogene 2001; 20 3880-3887.
25. Megidish $\mathrm{T}, \mathrm{Xu} \mathrm{JH}, \mathrm{Xu} \mathrm{CW}$. Activation of $\mathrm{p} 53$ by protein inhibitor of activated Stat1 (PIAS1). J Biol Chem 2002; 277: 8255-8259

26. Shuai K. Regulation of cytokine signaling pathways by PIAS proteins. Cell Res 2006; 16 : 196-202.

27. Linja MJ, Porkka KP, Kang Z, Savinainen KJ, Janne OA, Tammela TL et al. Expression of androgen receptor coregulators in prostate cancer. Clin Cancer Res 2004; 10: 1032-1040.

28. Chen P, Zhao D, Sun Y, Huang L, Zhang S, Yuan Y. Protein inhibitor of activated STAT-1 is downregulated in gastric cancer tissue and involved in cell metastasis. Oncol Rep 2012; 28: 2149-2155.

29. Coppola D, Parikh V, Boulware D, Blanck G. Substantially reduced expression of PIAS1 is associated with colon cancer development. J Cancer Res Clin Oncol 2009; 135: 1287-1291.

30. Wei J, Costa C, Ding Y, Zou Z, Yu L, Sanchez JJ et al. mRNA expression of BRCA1, PIAS1, and PIAS4 and survival after second-line docetaxel in advanced gastric cancer. J Natl Cancer Inst 2011; 103: 1552-1556.

31. Feng P, Liang JY, Li TL, Guan ZX, Zou J, Franklin R et al. Zinc induces mitochondria apoptogenesis in prostate cells. Mol Urol 2000; 4: 31-36.

32. Iguchi $\mathrm{K}$, Hamatake $\mathrm{M}$, Ishida $\mathrm{R}$, Usami $\mathrm{Y}$, Adachi $\mathrm{T}$, Yamamoto $\mathrm{H}$ et al. Induction of necrosis by zinc in prostate carcinoma cells and identification of proteins increased in association with this induction. Eur J Biochem 1998; 253: 766-770.

33. Liang JY, Liu YY, Zou J, Franklin RB, Costello LC, Feng P. Inhibitory effect of zinc on human prostatic carcinoma cell growth. Prostate 1999; 40: 200-207.

34. Timofeeva O, Nadler JV. Facilitation of granule cell epileptiform activity by mossy fiberreleased zinc in the pilocarpine model of temporal lobe epilepsy. Brain Res 2006; 1078: 227-234.

35. Moustakas A, Kardassis D. Regulation of the human p21/WAF1/Cip1 promoter in hepatic cells by functional interactions between $\mathrm{Sp} 1$ and Smad family members. Proc Natl Acad Sci USA 1998; 95: 6733-6738.

36. Tang MR, Wang YX, Guo S, Han SY, Wang D. CSMD1 exhibits antitumor activity in A375 melanoma cells through activation of the Smad pathway. Apoptosis 2012; 17: 927-937.

37. Franklin RB, Costello LC. The important role of the apoptotic effects of zinc in the development of cancers. J Cell Biochem 2009; 106: 750-757.

38. Costello LC, Franklin RB. Novel role of zinc in the regulation of prostate citrate metabolism and its implications in prostate cancer. Prostate 1998; 35: 285-296.

39. Yan M, Hardin K, Ho E. Differential response to zinc-induced apoptosis in benign prostate hyperplasia and prostate cancer cells. J Nutr Biochem 2010; 21: 687-694.

40. Zaichick V, Sviridova TV, Zaichick SV. Zinc in the human prostate gland: normal, hyperplastic and cancerous. Int Urol Nephrol 1997; 29: 565-574.

41. Klein C, Creach K, Irintcheva V, Hughes KJ, Blackwell PL, Corbett JA et al. Zinc induces ERK-dependent cell death through a specific Ras isoform. Apoptosis 2006; 11: 1933-1944.

42. Song K, Cornelius SC, Reiss M, Danielpour D. Insulin-like growth factor-I inhibits transcriptional responses of transforming growth factor-beta by phosphatidylinositol 3-kinase/Akt-dependent suppression of the activation of Smad3 but not Smad2. J Biol Chem 2003; 278: 38342-38351.

43. Petersen $M$, Pardali $E$, van der Horst $G$, Cheung $H$, van den Hoogen $C$, van der Pluijm $G$ et al. Smad2 and Smad3 have opposing roles in breast cancer bone metastasis by differentially affecting tumor angiogenesis. Oncogene 2010; 29: 1351-1361.

44. Tannehill-Gregg SH, Kusewitt DF, Rosol TJ, Weinstein M. The roles of Smad2 and Smad3 in the development of chemically induced skin tumors in mice. Vet Pathol 2004; 41: 278-282.

45. Chang CC, Lin DY, Fang HI, Chen RH, Shih HM. Daxx mediates the small ubiquitin-like modifierdependent transcriptional repression of Smad4. J Biol Chem 2005; 280: 10164-10173.

46. Levy C, Sonnenblick A, Razin E. Role played by microphthalmia transcription factor phosphorylation and its Zip domain in its transcriptional inhibition by PIAS3. Mol Cell Biol 2003: 23: 9073-9080.

47. Prigge JR, Schmidt EE. Interaction of protein inhibitor of activated STAT (PIAS) proteins with the TATA-binding protein, TBP. J Biol Chem 2006; 281: 12260-12269.

48. Datto $M B, Y u Y$, Wang XF. Functional analysis of the transforming growth factor beta responsive elements in the WAF1/Cip1/p21 promoter. J Biol Chem 1995; 270: 28623-28628.

49. Dennler S, Itoh S, Vivien D, ten Dijke P, Huet S, Gauthier JM. Direct binding of Smad3 and Smad4 to critical TGF beta-inducible elements in the promoter of human plasminogen activator inhibitor-type 1 gene. EMBO J 1998; 17: 3091-3100.

50. Sui G, Soohoo C, Affar el B, Gay F, Shi Y, Forrester WC. A DNA vector-based RNAi technology to suppress gene expression in mammalian cells. Proc Natl Acad Sci USA 2002: 99: 5515-5520.

51. Rasul A, Ding C, Li X, Khan M, Yi F, Ali M et al. Dracorhodin perchlorate inhibits PI3K/Akt and NF-kappaB activation, up-regulates the expression of p53, and enhances apoptosis. Apoptosis 2012; 17: 1104-1119.

52. Mattia M, Gottifredi V, McKinney K, Prives C. p53-Dependent p21 mRNA elongation is impaired when DNA replication is stalled. Mol Cell Biol 2007; 27: 1309-1320.

Cell Death and Disease is an open-access journal published by Nature Publishing Group. This work is licensed under a Creative Commons Attribution-NonCommercialNoDerivs 3.0 Unported License. To view a copy of this license, visit http://creativecommons.org/licenses/by-nc-nd/3.0/ 